\title{
Iko River Estuary: Anthropogenic impacts and the microbial community alterations
}

\author{
Augustine A Unimke ${ }^{1,}{ }^{*}$, Anthony A Ibiene ${ }^{2}$ and Phillip 0 Okerentugba ${ }^{2}$ \\ ${ }^{1}$ Department of Microbiology, Faculty of Biological Sciences, University of Calabar, PMB 1115, Calabar, Cross River State, \\ Nigeria. \\ ${ }^{2}$ Department of Microbiology, Faculty of Science, University of Port Harcourt, Rivers State, Nigeria.
}

Publication history: Received on 08 December 2020; revised on 16 December 2020; accepted on 18 December 2020

Article DOI: https://doi.org/10.30574/gscbps.2020.13.3.0399

\begin{abstract}
The contamination of the aquatic systems with heavy metals has been on the increase since the last century due to industrial activities and this has contributed greatly to the variations in the microbial community structure and function in the ecosystem. The natural and anthropogenic variations in microbiological and heavy metals analysis in Iko River estuary was analyzed using standard methods. From the result, it was observes that anthropogenic variations influence greatly the microbial proliferation as significantly $(\mathrm{p}<0.05)$ higher microbial levels were observed across all microhabitats (tidal water, intertidal water and benthic sediment) as well as stations (upstream - Okoro, midstream Kampa and downstream - Emeroke). It was observed that the sediment samples produced significantly $(\mathrm{p}<0.05)$ higher THB counts than tidal and intertidal water samples. Similar trends were observed for CUB, TF and CUF respectively. There was no significant difference $(\mathrm{p}>0.05)$ between the mean values of upstream, midstream and downstream. In all microhabitats and stations, the densities of crude oil-utilizing microorganisms were significantly $(\mathrm{p}<0.05)$ low compared to total heterotrophic counts. The total fungal counts were significantly $(\mathrm{p}<0.05)$ low compared to total heterotrophic bacteria counts. The result showed relatively higher concentrations of heavy metals in sediment than in tidal and intertidal water samples. The results indicate that the water and sediment samples show a remarkable variation in heavy metals and total petroleum hydrocarbon as a result of the great human activities in the estuary.
\end{abstract}

Keywords: Microbiological; Heavy metals; Microbial analysis; Molecular analysis; Petroleum hydrocarbons

\section{Introduction}

As an ecosystem, estuaries are under threat due to many anthropogenic activities such as pollution resulting from massive oil exploration especially in the Niger Delta, overfishing and other human activities. They are also threatened by sewage, coastal settlement, land clearance and much more. Estuaries are affected by events far upstream, and concentrate materials such as pollutants and sediments. Land run-off, industrial, agricultural, and domestic waste enter rivers and are discharged into estuaries [1]. Contaminants such as plastics, pesticides, furans, dioxins, phenols and heavy metals which do not disintegrate rapidly in the marine environment can be introduced. Such toxicants can accumulate in the tissues of many species of aquatic life in a process known as bioaccumulation. They also accumulate in benthic environments, such as estuaries and bay mud. A geological record of human activities of the last century showed that Chinese and Russian industrial pollution, such as phenols and heavy metals, has devastated fish stocks in the Amur River and damaged its estuary soil [2].

${ }^{*}$ Corresponding author: Augustine A. Unimke

Department of Microbiology, Faculty of Biological Sciences, University of Calabar, PMB 1115, Calabar, Cross River State, Nigeria. 
Estuaries tend to be naturally eutrophic because land runoff discharges nutrients into estuaries. With human activities, land run-off also now includes the many chemicals used as fertilizers in agriculture as well as waste from livestock and humans. Excess oxygen-depleting chemicals in the water can lead to hypoxia and the creation of dead zones [3].

The contamination of the aquatic system with heavy metals has been on the increase since the last century due to industrial activities [4]. These heavy metals are taken up by biological agents as cations. Among the heavy metals detected by WSF are $\mathrm{Pb}, \mathrm{Cu}, \mathrm{Zn}, \mathrm{Cd}, \mathrm{Ni}, \mathrm{Cr}$, and V. Nwajei and Gagophien [5] stated that Pb, Cr and V are among metals that pose hazard to living organisms. Heavy metals are non-biodegradable and are toxic under certain conditions [4].

Some heavy metals are essential trace elements, but may become toxic to life, including microorganisms at high concentrations, by forming complex compounds within the cell [6]. Because heavy metals are increasingly found in microbial habitats due to natural and industrial processes, microbes have evolved several mechanisms to tolerate the presence of these harmful agents such as efflux, complexation, or reduction of metal ions) or to use them as terminal electron acceptors in anaerobic respiration [7]. Thus far, tolerance mechanisms for metals such as copper, zinc, arsenic, chromium, cadmium, and nickel have been identified and described in detail.

\section{Material and methods}

\subsection{Microbiological analysis}

Sediment and water samples for microbial analysis were collected aseptically, labeled and stored in ice-packed plastic coolers and transported to the laboratory where analysis within 24 - 48 hours of collection was carried out. Prior to analysis, the sediment samples were homogenized and ten (10) g of each sample was weighed out, added to $90 \mathrm{ml}$ of sterile deionized water and vigorously shaken for 1 minute using a vortex shaker to dislodge the microbiota. This method disrupts the flocculent material and randomly disrupted the protists. Treated samples were allowed to settle for 10 minutes prior to withdrawal of supernatant for serial dilution. Ten-fold serial dilution of the sediment and water samples was carried out for enumeration of densities of the different microbial groups.

\subsubsection{Estimation of microbial densities of sediment and water samples}

Several methods and media were used for the enumeration of the various microbial groups. The densities of the following microbial groups were determined:

- Total heterotrophic bacteria (THB)

- Total fungi (TF)

- Crude-oil utilizing bacteria (CUB)

- Crude-oil utilizing fungi (CUF)

The basic analytical media employed in the course of this research included: nutrient agar (NA), Sabouraud dextrose agar (SDA), mineral salt medium (MSM), thiosulfate citrate-bile salts-sucrose agar (TCBS), Salmonella-Shigella agar (SSA) and agar-agar. The media were prepared according to manufacturer's recommendations (Difco, Biotech). The counts of total heterotrophic bacteria in sediment and water samples were determined by the pour plate techniques [8]

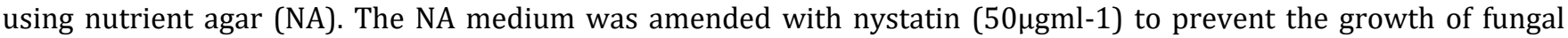
contaminants. The total fungal count was determined by pour plate technique using Sabouraud dextrose agar (SDA)

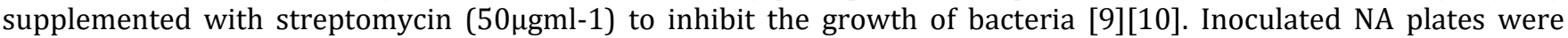
incubated at $280 \mathrm{C}$ for 24 hours, while the SDA plates were incubated at room temperature for 3 days before enumeration of microbial colonies.

\subsubsection{Isolation, purification and maintenance of pure microbial isolates}

Distinct or representative colonies from the culture plates were selected for characterization. Bacterial colonies were repeatedly transferred to freshly prepared nutrient agar plates by the streak-plate method and allowed to grow for 24 hours before stocking. Similarly, distinct fungal colonies were sub-cultured repeatedly on freshly prepared Sabouraud dextrose agar plates for 72 hours before stocking. Pure isolates of the microorganisms were maintained on agar slants as stock, and preserve in the refrigerator for further use.

\subsubsection{Enumeration of crude oil-utilizing microorganisms}

The counts of crude oil-utilizing bacteria and fungi were enumerated by pour plate techniques [11] using vapour phase transfer technique on mineral salt medium (MSM). For the enumeration of oil-degrading bacteria, the medium was 
supplemented with $30 \mathrm{mgl}-1$ fungizol miconazole nitrate to prevent the growth of fungal contaminants. On the other hand, mineral salts medium supplemented with $50 \mu \mathrm{gml}-1$ streptomycin to inhibit the growth of bacterial contaminants was used to ensure the enumeration of oil-degrading fungi. In both cases, the crude oil used was sterilized by millipore filtration $(0.45 \mu \mathrm{m}$ pore size $)$ and stored in sterile bottles. The oil agar plates were incubated at room temperature for 5 days before enumeration [12].

\subsection{PCR reaction for characterization and identification of isolates}

The PCR reaction was performed on the extracted DNA samples using universal degenerate primers $27 \mathrm{~F} .1$ Forward 5'AGRGTTTGATCMTGGCTCAG 3 and 1492R reverse 5'GGTTACCTTGTTACGACTT 3' that amplifies the entire 16s Variable region at annealing temperature of 58. Similarly, universal degenerate primers were used to amplify ribosomal internal transcribed spacer (ITS). The primers sequences were ITS1: 5’TCC GTA GGT GAA CCT TGC GG 3 and ITS4 5’TCC TCC GCT TAT TGA TAT GC 3'. Each PCR reaction contained $5 \mu$ of $10 \times$ Taq buffer, $2 \mathrm{mMMgCl} 2,1.5 \mathrm{U}$ Super-Therm DNA Polymerase (Southern Cross), $0.25 \mathrm{mMdNTP}$ 's, $0.1 \mu \mathrm{M}$ of each primer, $1 \mu$ l of extracted DNA and Nuclease Free Water (NFW) up to the final reaction volume of $50 \mu \mathrm{l}$. Few microliters of the samples were run on a $1 \%$ agarose gel at $90 \mathrm{~V}$ for $30 \mathrm{~min}$ in order to verify amplification to check presence of amplification band corresponding to expected band size1.

DNA sequencing was performed by Sanger (dideoxy) sequencing Technique to determine the nucleotide sequence of the specific microorganism isolated using automated PCR cycle-Sanger Sequencer ${ }^{\mathrm{TM}}$ ABI3500XL DNA Analyzers from Applied Biosystems. Sequencing was then done with the ABI V3.1 Big dye kit according to manufacturer's instructions. The cleaned products were then injected on the analysers with a $50 \mathrm{~cm}$ array, using POP7. Sequencing data were obtained and read on a Geospiza FINCH TV software version 1.4.0, Chromatogram viewer that can display DNA sequence traces on Windows.

\subsection{Analysis of heavy metals}

Analysis of heavy metals was done after finely grounding the sediment samples to facilitate the digestion of $1 \mathrm{~g}$ of the sample with perchloric acid and nitric acid. Heavy metal content of the sediment digests and water samples was determined using atomic absorption spectrophotometer (Model UNICAM 939).

\section{Results and discussion}

The results presented in Tables 1 represent the mean values of total heterotrophic bacteria (THB), crude oil-utilizing bacteria (CUB), total fungi (TF), and crude oil-utilizing fungi (CUF) respectively. The results showed that anthropogenic variations influence greatly the microbial proliferation as significantly $(\mathrm{p}<0.05)$ higher microbial levels were observed across all microhabitats (tidal water, intertidal water and benthic sediment) as well as stations (upstream - Okoro, midstream - Kampa and downstream - Emeroke).

It was observed that the sediment samples produced significantly $(\mathrm{p}<0.05)$ higher THB counts than tidal and intertidal water samples. Similar trends were observed for CUB, TF and CUF respectively. There was no significant difference ( $p>0.05)$ between the mean values of upstream, midstream and downstream. In all microhabitats and stations, the densities of crude oil-utilizing microorganisms were significantly $(\mathrm{p}<0.05)$ low compared to total heterotrophic counts. The total fungal counts were significantly $(\mathrm{p}<0.05)$ low compared to total heterotrophic bacteria counts.

The mean values of THB for tidal water were $1.46 \pm 0.19\left(\mathrm{x} 10^{7}\right), 1.60 \pm 0.62\left(\mathrm{x} 10^{7}\right)$ and $1.58 \pm 0.53\left(\mathrm{x} 10^{7}\right)$ for upstream, midstream and downstream respectively, while the mean values for CUB were $1.11 \pm 0.12\left(\mathrm{x} 10^{6}\right), 1.24 \pm 0.52\left(\mathrm{x} 10^{6}\right)$ and $1.28 \pm 0.42\left(\mathrm{x} 10^{6}\right)$ for upstream, midstream and downstream respectively. Similarly, the mean values for TF and CUF were $1.18 \pm 0.13\left(\mathrm{x} 10^{6}\right), 1.18 \pm 0.24\left(\mathrm{x} 10^{6}\right), 1.26 \pm 0.20\left(\mathrm{x} 10^{6}\right)$ and $7.6 \pm 0.86\left(\mathrm{x} 10^{4}\right), 9.2 \pm 0.21\left(\mathrm{x} 10^{4}\right), 8.8 \pm 0.26\left(\mathrm{x} 10^{4}\right)$ for upstream, midstream and downstream respectively. For intertidal water, the mean values obtained for upstream, midstream and downstream were $9.8 \pm 0.75\left(\mathrm{x} 10^{6}\right), 1.84 \pm 0.52\left(\mathrm{x} 10^{7}\right)$ and $1.44 \pm 0.30\left(\mathrm{x} 10^{7}\right)$ for THB, $1.22 \pm 0.91\left(\mathrm{x} 10^{6}\right)$, $1.20 \pm 0.20\left(\mathrm{x} 10^{6}\right)$ and1.18 $\pm 0.22\left(\mathrm{x} 10^{6}\right)$ for CUB, $1.06 \pm 0.60\left(\mathrm{x} 10^{6}\right), 1.44 \pm 0.32\left(\mathrm{x} 10^{6}\right)$ and $1.24 \pm 0.20\left(\mathrm{x} 10^{6}\right)$ for TF and $7.6 \pm 0.82\left(\mathrm{x} 10^{4}\right), 9.6 \pm 0.6\left(\mathrm{x} 10^{4}\right), 8.8 \pm 0.24\left(\mathrm{x} 10^{4}\right)$ for CUF). While the values for benthic sediment were $1.72 \pm 0.50\left(\mathrm{x} 10^{8}\right)$, $1.77 \pm 0.34\left(\mathrm{x} 10^{8}\right), 2.16 \pm 0.34\left(\mathrm{x} 10^{8}\right)$ for $\mathrm{THB}, 1.26 \pm 0.43\left(\mathrm{x} 10^{7}\right), 1.28 \pm 0.90\left(\mathrm{x} 10^{7}\right), 1.54 \pm 0.96\left(\mathrm{x} 10^{7}\right)$ for CUB, $1.22 \pm 0.76$ $\left(\mathrm{x} 10^{7}\right), 1.26 \pm 0.64\left(\mathrm{x} 10^{7}\right), 1.46 \pm 0.15\left(\mathrm{x} 10^{7}\right)$ for TF and $9.2 \pm 0.15\left(\mathrm{x} 10^{5}\right), 6.4 \pm 0.40\left(\mathrm{x} 10^{5}\right), 1.14 \pm 0.12\left(\mathrm{x} 10^{6}\right)$ for CUF. The microbial species identified from the molecular analysis were: Pseudomonas putida, Lysinbacillus macroides, Rhodococcus equi, Achromobacter xylosoxidans, Enterobacter cloacae,Bacillus mega, Marinobacter hydrocarbonoclastius, Penicillium citrinum, Aspergillus aculeatus and Tinctoporellus epiphiltinus. 
The result of the heavy metals analysis of the water and sediment samples is as shown Figures $1-3$, while the results of the total petroleum hydrocarbons is shown in Figures $4-6$ below. The heavy metals analyzed were: copper (Cu), cobalt (Co), manganese (Mn), nickel (Ni), lead (Pb), arsenic (As), zinc ( $\mathrm{Zn}$ ), chromium (Cr) and vanadium (V). In the tidal and intertidal water samples, the results showed that there was no significant difference $(p>0.05)$ in the mean values of each parameter. Meanwhile, benthic sediment samples produced significantly $(\mathrm{p}<0.05)$ higher mean values than the tidal and intertidal water samples.

The massive microbial communities and relevant functions in contaminated environments such as Iko River estuary provide a great opening for environmental impact strategies as revealed in this study. The results obtained in this study revealed great microbial load as significantly $(\mathrm{p}<0.05)$ higher levels were obtained across all microhabitats (tidal water, intertidal water and benthic sediment) as well as stations (upstream - Okoro, midstream - Kampa and downstream Emeroke). The sediment samples in the study produced significantly $(\mathrm{p}<0.05)$ higher THB counts than tidal and intertidal water samples. The study revealed conforming results for CUB, TF and CUF. There was no significant difference $(p>0.05)$ across the various microhabitats, while the densities of crude oil-utilizing microorganisms were significantly $(\mathrm{p}<0.05)$ low in relation to total heterotrophic counts. Unlike the total heterotrophic bacteria counts, the total fungal counts were significantly $(\mathrm{p}<0.05)$ low compared to total fungi.

The high levels of microbial counts observed in the estuary were as a result of the massive petroleum and other related activities in the area under study resulting in an enriched microbial population surviving toxic contamination [13].

The contamination of the aquatic system with heavy metals has been on the increase since the last century due to industrial activities [14]. The heavy metals analyzed in the present study were all detected throughout the study. This is in agreement with the report of Carvalho et al. [15] that heavy metals are some of the most toxic, persistent and widespread contaminants in estuarine ecosystems.

The relatively higher concentrations of heavy metals in sediment than in tidal and intertidal water may be ascribed to the sedimentation, percolation and flocculation patterns in the aquatic ecosystem. The results obtained indicate that the water and sediment samples show a remarkable variation in heavy metals and total petroleum hydrocarbon as a result of the great human activities in the estuary.

Table 1Microbial analysis of tidal, intertidal and benthic water samples

\begin{tabular}{|l|l|l|l|}
\hline Sampling locations/Parameters & Upstream (Okoro) & Midstream (Kampa) & Downstream (Emeroke) \\
\hline Tidal water (TW) (cfu/ml) & & & \\
\hline THB & $\mathrm{b} 1.46 \pm 0.19\left(\mathrm{x} 10^{7}\right)$ & $\mathrm{a} 1.60 \pm 0.62\left(\mathrm{x} 10^{7}\right)$ & $\mathrm{a} 1.58 \pm 0.52\left(\mathrm{x} 10^{7}\right)$ \\
\hline CUB & $\mathrm{a} 1.11 \pm 0.12\left(\mathrm{x} 10^{6}\right)$ & $\mathrm{b} 1.24 \pm 0.52\left(\mathrm{x} 10^{6}\right)$ & $\mathrm{b} 1.28 \pm 0.42\left(\mathrm{x} 10^{6}\right)$ \\
\hline TF & $\mathrm{a} 1.18 \pm 0.13\left(\mathrm{x} 10^{6}\right)$ & $\mathrm{a} 1.18 \pm 0.24\left(\mathrm{x} 10^{6}\right)$ & $\mathrm{a} 1.26 \pm 0.20\left(\mathrm{x} 10^{6}\right)$ \\
\hline CUF & $\mathrm{a} 7.6 \pm 0.86\left(\mathrm{x} 10^{4}\right)$ & $\mathrm{a} 9.2 \pm 0.21\left(\mathrm{x} 10^{4}\right)$ & $\mathrm{a} 8.8 \pm 0.26\left(\mathrm{x} 10^{4}\right)$ \\
\hline Intertidal water (ITW) (cfu/ml) & & & \\
\hline THB & $\mathrm{a} 9.8 \pm 0.75\left(\mathrm{x} 10^{6}\right)$ & $\mathrm{b} 1.84 \pm 0.52\left(\mathrm{x} 10^{7}\right)$ & $\mathrm{c} 1.44 \pm 0.30\left(\mathrm{x} 10^{7}\right)$ \\
\hline CUB & $\mathrm{a} 1.22 \pm 0.91\left(\mathrm{x} 10^{6}\right)$ & $\mathrm{a} 1.20 \pm 0.20\left(\mathrm{x} 10^{6}\right)$ & $\mathrm{a} 1.18 \pm 0.22\left(\mathrm{x} 10^{6}\right)$ \\
\hline TF & $\mathrm{a} 1.06 \pm 0.60\left(\mathrm{x} 10^{6}\right)$ & $\mathrm{b} 1.44 \pm 0.32\left(\mathrm{x} 10^{6}\right)$ & $\mathrm{c} 1.24 \pm 0.20\left(\mathrm{x} 10^{6}\right)$ \\
\hline CUF & $\mathrm{a} 7.6 \pm 0.82\left(\mathrm{x} 10^{4}\right)$ & $\mathrm{a} 9.6 \pm 0.6\left(\mathrm{x} 10^{4}\right)$ & $\mathrm{a} 8.8 \pm 0.24\left(\mathrm{x} 10^{4}\right)$ \\
\hline Benthic sediment (BSD) (cfu/g) & & & \\
\hline THB & $\mathrm{a} 1.72 \pm 0.50\left(\mathrm{x} 10^{8}\right)$ & $\mathrm{a} 1.78 \pm 0.36\left(\mathrm{x} 10^{8}\right)$ & $\mathrm{b} 2.16 \pm 0.34\left(\mathrm{x} 10^{8}\right)$ \\
\hline CUB & $\mathrm{a} 1.26 \pm 0.43\left(\mathrm{x} 10^{7}\right)$ & $\mathrm{a} 1.28 \pm 0.90\left(\mathrm{x} 10^{7}\right)$ & $\mathrm{b} 1.54 \pm 0.96\left(\mathrm{x} 10^{7}\right)$ \\
\hline TF & $\mathrm{a} 1.22 \pm 0.76\left(\mathrm{x} 10^{7}\right)$ & $\mathrm{a} 1.26 \pm 0.64\left(\mathrm{x} 10^{7}\right)$ & $\mathrm{a} 1.46 \pm 0.15\left(\mathrm{x} 10^{7}\right)$ \\
\hline CUF & $\mathrm{b} 9.2 \pm 0.15\left(\mathrm{x} 10^{5}\right)$ & $\mathrm{a} 6.4 \pm 0.40\left(\mathrm{x} 10^{5}\right)$ & $\mathrm{a} 1.14 \pm 0.12\left(\mathrm{x} 10^{6}\right)$ \\
\hline
\end{tabular}

Similar superscripts represent significant mean \pm SD across the rows for each of the parameters for tidal water, intertidal water and benthic sediment 


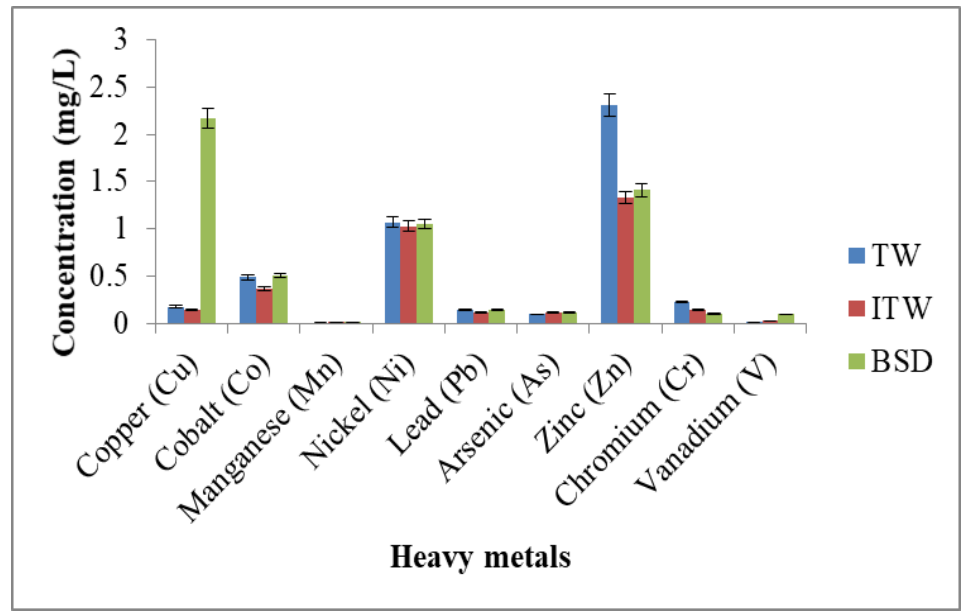

Figure 1 Mean values of heavy metals for Upstream(ANOVA $p=0.72$---- Not significant) KEY TW = Tidal water, ITW = Intertidal water, BSD = Benthic sediment.

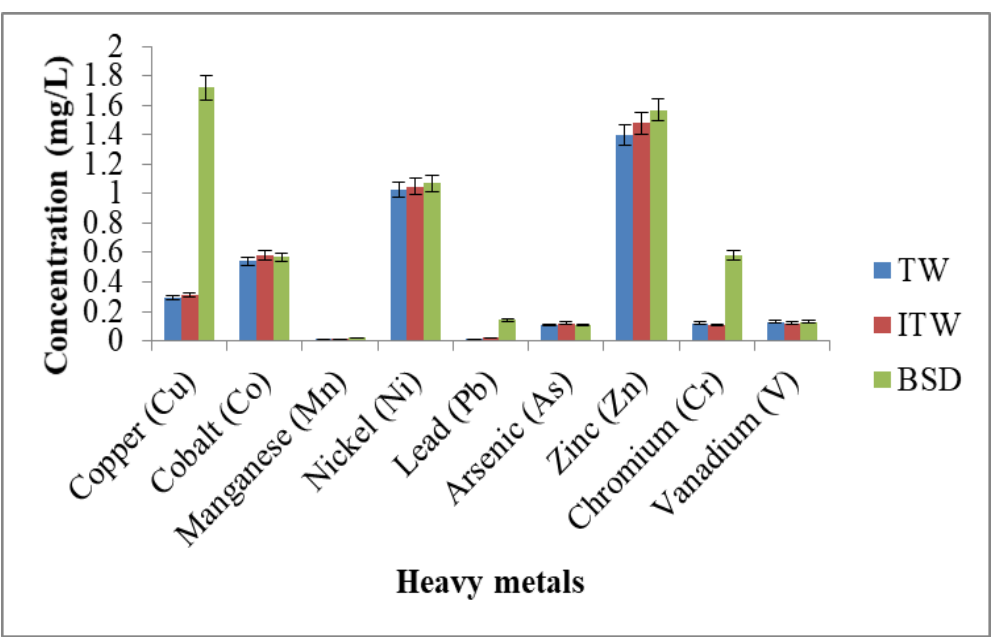

Figure 2 Mean values of heavy metals for Midstream (ANOVA $p=0.57$---- Not Significant) KEY: TW $=$ Tidal water, ITW $=$ Intertidal water, BSD $=$ Benthic sediment

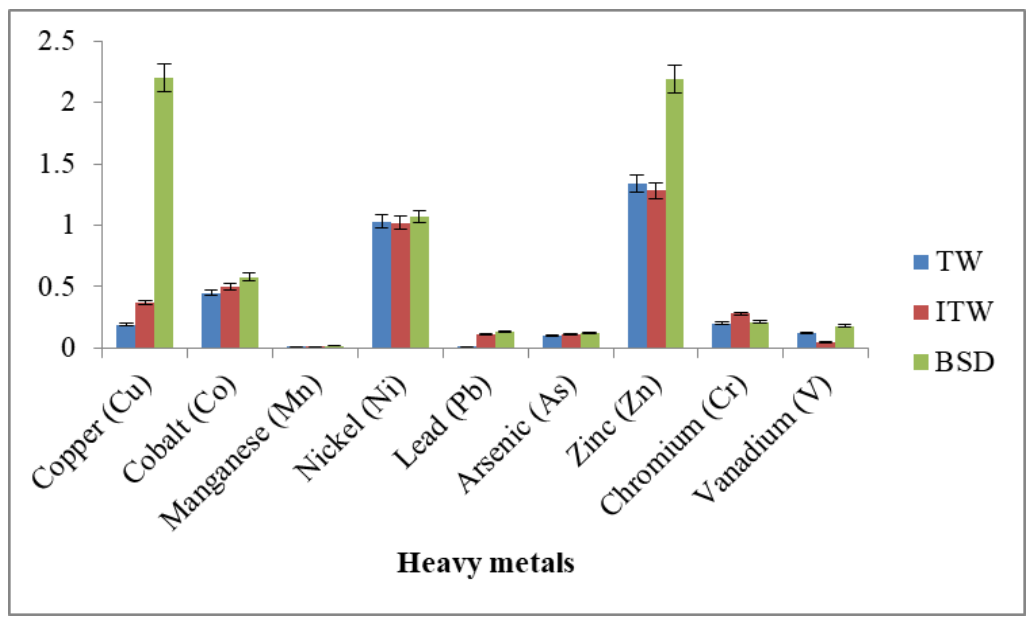

Figure 3 Mean values of heavy metals for Downstream (ANOVA p $=0.42$---- Not significant) KEY: TW $=$ Tidal water, $\mathrm{ITW}=$ Intertidal water, $\mathrm{BSD}=$ Benthic sediment 


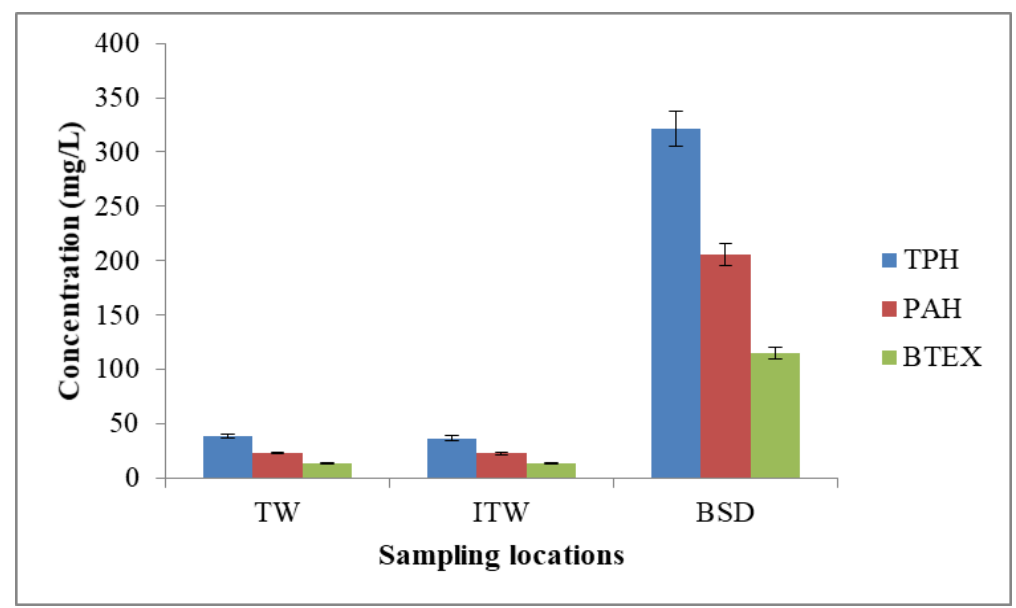

Figure 4 Mean values of hydrocarbon content for Upstream (ANOVA $p=0.013$---- significant) KEY: TW $=$ Tidal water, $\mathrm{ITW}=$ Intertidal water, $\mathrm{BSD}=$ Benthic sediment

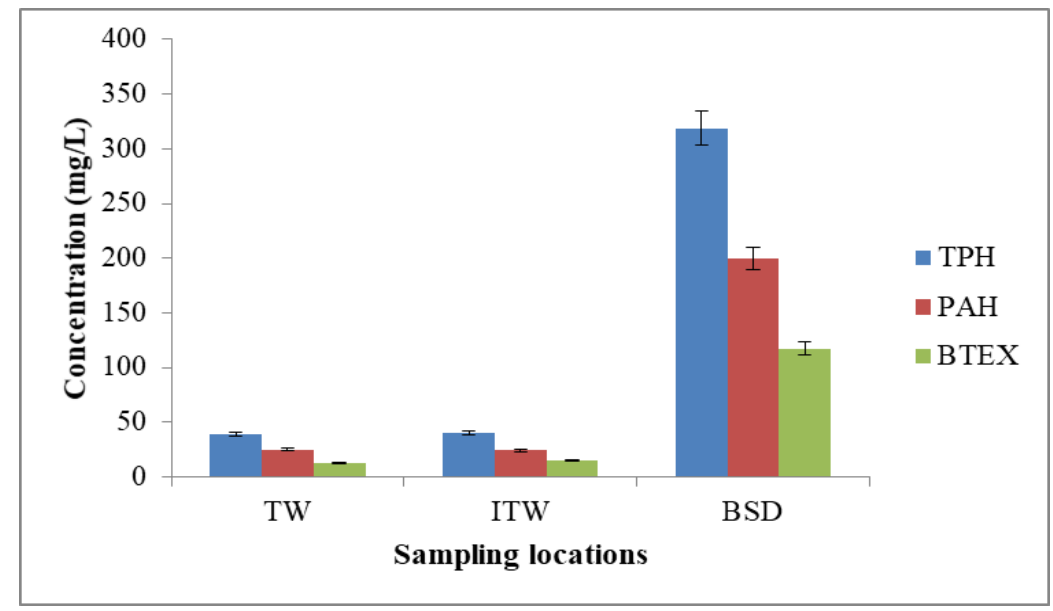

Figure 5 Mean values of hydrocarbon content for Midstream (ANOVA $p=0.013$---- significant) KEY: TW $=$ Tidal water, ITW $=$ Intertidal water, $\mathrm{BSD}=$ Benthic sediment.

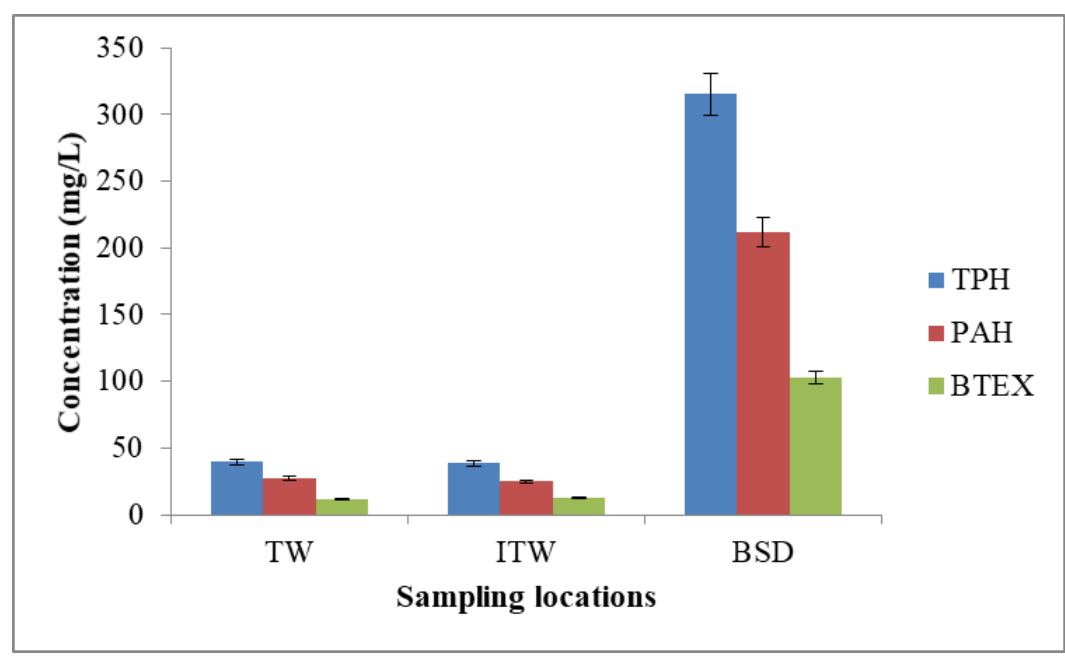

Figure 6 Mean values of hydrocarbon content for Downstream (ANOVA $\mathrm{p}=0.02$---- significant) KEY: TW $=$ Tidal water, $\mathrm{ITW}=$ Intertidal water, $\mathrm{BSD}=$ Benthic sediment 


\section{Conclusion}

The tremendous variations observed in the microbiological and heavy metal analysis in all the stations revealed the massive human activity in the estuary due mainly to the oil exploration and other relative activities in the area. The sediment sample produced higher levels of microbial counts than the tidal and intertidal water samples. The high counts of hydrocarbon-utilizing microbes obtained serve as a sensitive index of environmental exposure to hydrocarbon and metal pollution in the estuary. The results of this study revealed the level of human impacts in the study environment. Strong affinity between the heavy metals was observed in the estuary despite their variability. This suggests their common origin, which may be ascribed to crude oil pollution in the site. The presence of hydrocarbonoclastic microorganisms in the estuary implies that they are actively involved in the biodegradation and other processes. These variations in microbiological and heavy metal observed from the results may be use in environmental analysis to determine the level of pollution in the ecosystem.

\section{Compliance with ethical standards}

\section{Acknowledgments}

The Authors sincerely thank the Tertiary Education Trust Fund (TetFund), Nigeria and the University of Calabar for sponsoring this research

\section{Disclosure of conflict of interest}

The authors have declared that no conflict of interest exists.

\section{References}

[1] Kaiser, DE. Marine Ecology. Processes, Systems and Impacts. New York: Oxford University Press. 2005; 77-85.

[2] Ross DA. Introduction to Oceanography. New York: Harper Collins College Publishers. 1995; 37-46.

[3] Branch G. Estuarine vulnerability and ecological impacts: Estuaries of South Africa, in Brian, R. A and Dan, B (eds.). Trends in Ecology \& Evolution. 2012;14: 499.

[4] Asaolu SS, Olaofe 0. Biomagnification factors of some heavy and essential metals in sediments, fish and crayfish from Ondo State coastal region. Biological Science Research Community. 2004; 16: 33-39.

[5] Nwajei GE, Gagophien PO. Distribution of heavy metals in the sediments of Lagos Lagoon, Pakistani Journal of Science and Industrial Research. 2000; 43:338-340.

[6] UnimkeAA,Antai SP, Agbor RB, Nseabasi NO,Agbo BE. Evaluation of Seasonal Variation in the Microbial and Heavy Metal Concentrations of Imo River Estuary of the Niger Delta Mangrove Ecosystem. Advanced Research in Agriculture and Veterinary Science. 2014; 1(2): 88 - 94.

[7] Ober AG, González M, Santa- Maria I. Heavy metals in molluscan, crustacean, and other commercially important Chilean marine coastal water species. Bulletin of Environmental Contamination and Toxicology. 1987; 38: 534539.

[8] Chikere CB, Okpokwasili GC, Chikere BO. Bacterial diversity in a tropical crude oil-polluted soil undergoing bioremediation. African Journal of Biotechnology. 2009; 8: 2535-2540.

[9] Martini A, Federia F,Rosini G. A new approach to the study of yeast ecology of natural substrates. Canadian Journal of Microbiology. 1980; 26: 854-860.

[10] Barnett HL, Hunter BB. Illustrated Genera of Imperfect Fungi. New York, Macmillan Publishing Company. 1987; 122-179.

[11] Mills AL, Breuil C, Colwell. Enumeration of petroleum degrading marine and estuarine microorganisms by most probable number method. CanadianJournal of Microbiology. 1978; 12: 234 - 248.

[12] AA Unimke, AO Mmuoegbulam, IU Bassey,SE Obot. Assessment of the Microbial Diversity of Spent-Oil Contaminated Soil in Calabar, Nigeria. Journal of Advances in Microbiology. 2017; 4(4): 1-9.

[13] AA Unimke, OA Mmuoegbulam,OC Anika. Microbial Degradation of Petroleum Hydrocarbons: Realities, Challenges and Prospects. Biotechnology Journal International. 2018; 22(2): 1 - 10. 
[14] Florea A, Busselberg D. Occurrence, use and potential toxic effects of metal and metal compounds. Biometals. 2006; 19: 419-427.

[15] Carvalho RA, Benfield MC,Santschi PH. Comparative bioaccumulation studies of colloidally complexed and freeionic heavy metals in juvenile brown-shrimp. Limnological Oceanography. 1999; 44: 403-414.

\section{Author's short biography}

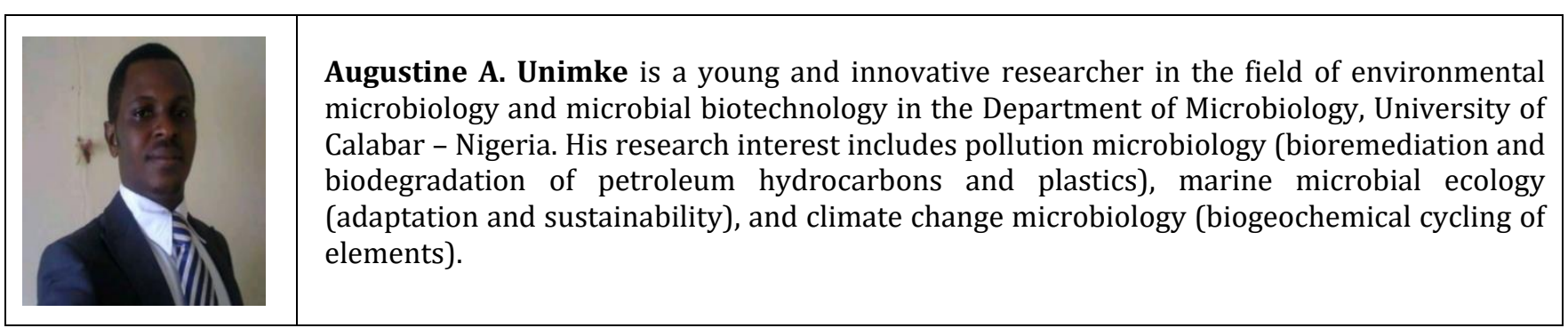

